\title{
Pattern of Dental Diseases among SubJects ATtENDING A SHORT-TERM MEDICAL MISSION Project IN UROMI, Nigeria
}

Editor,

Dental care is now a common component of medical missions organized by non-governmental or faith-based organizations. Short-term missions engage volunteer health care workers who operate for short periods mostly in deprived communities. Their activities are often sporadic, irregular and difficult to follow up. They are also limited by availability of dental supplies, quality of volunteers and political considerations. ${ }^{1}$ Nevertheless the basic epidemiological information gathered can aid in the planning effective and efficient primary oral health care services which are urgently required in Nigeria, ${ }^{2,3}$ hence the need to conduct this survey.

Subjects attending a one-week free health care project were seen in local dental clinic. Examination was conducted according to World Health Organization criteria ${ }^{4}$ using dental materials, sterilizing solution (Cidex $(R)^{\prime}$ and personal protective equipment (PPE) provided by Pro- Health
International. A structured self-administered questionnaire was filled by participants and consent was implied. Data gathered was analyzed at University of Benin Computer Center using SPSS 10.0. Seventy-eight subjects were seen with a mean age of $33 \pm 15.6$ years. Age range was $6-75$ years (Table 1). Fifty of the patients (64\%) were females. The age group $16-30$ years $(37.2 \%)$ accounted for the highest proportion of the clinic attendees. The total mean Decayed, Missing and filled teeth (DMFT) was $3.3 \pm 4.1$. Only $28 \%$ were caries- free (Figure 1 ). Females had a higher DMFT $(3.7 \pm 4.4)$ than males DMFT (2.6 \pm 3.4$)$ The percentages of healthy gum, bleeding on probing, calculus, shallow and deep pockets of $9.0 \%, 3.8 \%, 35.9 \%, 37.2 \%$ and $14.1 \%$ respectively. Well water (87\%) accounted for the major source of drinking water. Only about $18 \%$ had knowledge of dental caries, $10 \%$ of periodontal disease while nearly $30 \%$ claimed a previous dental visit/ contact with dental personnel.

Table 1. Previous Dental Visit by Age Distribution

\begin{tabular}{llll}
\hline Age (years) & \multicolumn{2}{l}{ Previous visit to dentist } & Total (\%) \\
\cline { 2 - 3 } & Yes (\%) & No (\%) & \\
$6-15$ & $3(3.8)$ & $10(12.8)$ & $11(14.1)$ \\
$16-30$ & $8(10.3)$ & $21(26.9)$ & $29(37.2)$ \\
$31-45$ & $9(11.5)$ & $15(19.2)$ & $24(30.8)$ \\
$46-60$ & $3(3.8)$ & $6(7.7)$ & $9(11.5)$ \\
$61-75$ & - & $5(6.4)$ & $5(6.4)$ \\
\hline Total & $23(29.5)$ & $55(70.5)$ & $78(100)$ \\
\hline
\end{tabular}

Figure 1. Pattern of periodontal diseases among subjects

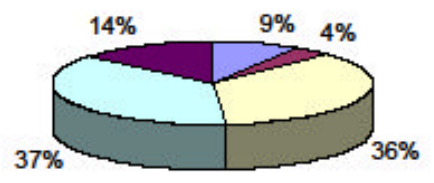

$$
\begin{aligned}
& \square \text { Healthy } \\
& \square \text { Bleeding } \\
& \square \text { Calculus } \\
& \square \text { Shallow Pocket } \\
& \square \text { Deep pocket }
\end{aligned}
$$

The results indicate poor oral health of the participants and reflect not only the increased disease burden in those who seek free dental care offered by short-term mission services but also lack of access to primary oral health care, an integral component of Primary Health Care (PHC). ${ }^{5}$ The use of untreated well water underscores the need for its fluoride analysis.

\section{S. A. Okeigbemen}

Community Dental Health Unit, Department of Preventive Dentistry, University of Benin, Benin City, Edo State, Nigeria. E-mail: svokeigbemen@gmail.com Tel: $+234-8056546215$ 


\section{References}

1. Simoyan O. Public Health: A dentist's perspective. Archives of Ibadan Medicine. 1999; 1(suppl):17-20.

2. Adegbembo AO, el-Nadeef MA, Adeyinka A. National survey of dental caries status and treatment needs in Nigeria. Int Dent J. 1995; 45:35-44.

3. Kallio P, Ainamo J. Periodontal Disease, Dental caries and tooth loss in two Nigerian Populations. Afr Dent J. 1988; 2:61-64.

4. World Health Organization. Oral health surveys - Basic methods. Third Edition. Geneva: WHO, 1987.

5. Jeboda SO, Eriksen HM. Primary Oral Health care. The concepts and suggestions for practical approach. Odontostomagie Tropicale. 1998; XI: 121-126. 